Aksiologiya: Jurnal Pengabdian Kepada Masyarakat

Vol.4, No.2, Agustus 2020 Hal 190 - 198

ISSN 2528-4967 (print) dan ISSN 2548-219X (online)

\title{
Pelatihan Blended Learning Sebagai Upaya Menghadapi Society 5.0
}

\author{
Edi Irawan ${ }^{1}$ \\ Institut Agama Islam Negeri Ponorogo \\ Email: nawariide@iainponorogo.ac.id
}

\begin{abstract}
ABSTRAK
Hadirnya revolusi industri 4.0 dan society 5.0 menjadi inspirasi pelaksanaan kegiatan pengabdian masyarakat ini. Kegiatan ini dilaksanakan dalam rangka untuk mempersiapkan sejak dini, agar para guru dan siswa tidak mampu bersaing dan menangkap peluang di masa yang akan datang. Pendekatan yang digunakan pada kegiatan ini adalah participatory action research (PAR) dengan subjek dampingan yang menjadi mitra kegiatan pengabdian masyarakat ini adalah Madrasah Aliyah Al-Ishlah Bungkal, Ponorogo. Kegiatan dilaksanakan dalam tiga tahap, yaitu identifikasi masalah, pelaksanaan kegiatan, dan evaluasi pelaksanaan. Hasil pelaksanaan kegiatan ini adalah pemahaman peserta yang tinggi terhadap materi yang disajikan, baik tentang revolusi industri 4.0, society 5.0, dan blended learning serta keterampilan peserta dalam menggunakan Google Classroom dalam pembelajaran. Indikator lain keberhasilan pelaksanaan pengabdian kepada masyarakat ini adalah hasil evaluasi peserta terhadap pelaksanaan kegiatan. Sebagian besar peserta menyatakan bahwa kegiatan sangat baik, baik pada aspek sistematika materi, kesesuaian materi, alokasi waktu setiap materi, cara penyampaian materi, kesempatan mengajukan pertanyaan, interaksi narasumber dengan peserta seminar, kualitas materi yang disampaikan, relevansi materi dengan kebutuhan, maupun kemenarikan materi yang disampaikan.
\end{abstract}

Kata Kunci: blended learning, Google Classroom, revolusi industri 4.0, society 5.0

\section{Blended Learning Training as an Effort to Face Society 5.0}

\begin{abstract}
The presence of the industrial revolution 4.0 and society 5.0 inspired the implementation of this community service activity. This activity is carried out to prepare early so that teachers and students are not able to compete and seize opportunities in the future. The approach used in this activity is participatory action research (PAR) with the assisted subject being the partner of community service activities is Madrasah Aliyah Al-Ishlah Bungkal, Ponorogo. Activities carried out in three stages, namely identification of problems, implementation of activities, and evaluation of implementation. The results of the implementation of this activity were participants 'high understanding of the material presented, both about the industrial revolution 4.0, society 5.0, and blended learning and the participants' skills in using Google Classroom in learning. Another indicator of the successful implementation of community service is the outcome of the participant's evaluation of the implementation of the activity. Most of the participants stated that the activity was very good, both in the systematic aspects of the material, the suitability of the material, the time allocation of each material, how to deliver the material, the opportunity to ask questions, the interviewees with the seminar participants, the quality of the material delivered, the relevance of the material to the needs, and the attractiveness of the material delivered.
\end{abstract}

Key Words: blended learning, Google Classroom, revolusi industri 4.0, society 5.0 


\section{PENDAHULUAN}

Society 5.0 menjadi isu terkini yang menarik dan penting untuk disikapi. Jika sebelumnya revolusi industri 4.0, yang dipopulerkan oleh Schwab di Jerman (Soemantri, 2019), kini pemerintah Jepang memaparkan visi peradaban masa depan yang dikenal dengan era society 5.0.

Revolusi industri 4.0 merupakan tahapan termutakhir dari berbagai fase revolusi industri. Revolusi industri 1.0 ditandai dengan adanya penemuan mesin uap, kemudian revolusi industri 2.0 ditandai dengan adanya penemuan listrik, dan revolusi industri 3.0 ditandai dengan penemuan komputer danjuga internet. Selanjutnya, revolusi industri 4.0 lahir karena pemanfaatan AI (artificial intelegensi /kecerdasan buatan), robotika, mesin cetak tiga dimensi, dan big data (Irawan, 2019; Schwab, 2017).

Sementara itu, society 5.0 lebih menekankan pada pentahapan peradaban manusia. Society 1.0 merupakan peradaban dimana manusia masih hidup dengan berburu, kemudian pada society 2.0 manusia sudah mengenal bercocok tanam dalam pertanian, selanjutnya pada society 3.0 manusia sudah mengenal industri, dan pada society 4.0 manusia sudah mengenal dan memanfaatkan teknologi informasi dan komunikasi dalam kehidupan (Harayama, 2017; Salgues, 2018; Shiroishi et al., 2018).

Society 5.0 merupakan visi pemerintah Jepangyangmenjadi solusi permasalahan mereka selama ini. Fase yang diklaim menjadi peradaban kelima ini nanti akan memanfaatkan big data, kecerdasan buatan, dan robot sebagai berikut.

1. Permasalahan transportasi akan diatasi dengan adanya mobil dan bis tanpa pengemudi, yang bisa dipesan dengan mudah. Karenanya, masyarakat tidak perlu memiliki kendaraan sendiri, dan cukup memanfaatkan kendaraan umum tanpa kemudi ini.

2. Permasalahan dibidang kesehatan, di mana para manula yang kesulitan untuk berobat karena tidak ada yang merawat, akan teratasi dengan adanya big data yang menyimpan data riwayat kesehatan seluruh penduduk.

3. Permasalahan pengiriman barang akan teratasi dengan adanya drone yang dapat mengantar barang dengan cepat dan aman.

4. Kebutuhan tenaga untuk angkat barangakanteratasi denganadanya robot yang mampu memindah barang sesuai kebutuhan.

5. Efisiensi perawatan jalan dan jembatan dengan memanfaatkan sensor untuk mendeteksi kerusakan dan penyelesaian menggunakan robot (Harayama, 2017; Salgues, 2018; Shiroishi et al., 2018).

Di saat negara-negara lain sudah menetapkan visinya untuk masa depan mereka, kita tentu perlu belajar dan memberikan respons yang baik. Pasalnya, dampak darirevolusi industri 4.0 dan society 5.0, perlahan tapi pasti akan terasa juga di Indonesia. Salah satu dampaknya adalah pada bidang pendidikan. Karenanya, pendidikan harus mampu memfasilitasi dan mengoptimalkan potensi siswa untuk menjadi bekal mengarungi peluang sekaligus tantangan revolusi industri 4.0 dan society 5.0. 
Dampak yang akan timbul dari revolusi industri 4.0 dan society 5.0 adalah banyaknya aktivitas dan pekerjaan manusia yang tergantikan oleh mesin atau teknologi yang didukung dengan pemanfaatan kecerdasan buatan, big data, robotika, dan sensor. Karenanya, kehadiran era disrupsi teknologi ini diprediksi akan menghilangkan sekitar 1 hingga 1,5 miliar pekerjaan sepanjang tahun 2015-2025 karena peran manusia digantikan oleh mesin otomatis (Leonhard, 2016). Dampak lainnya adalah, diprediksi juga sebanyak $65 \%$ siswa sekolah dasar di dunia akan bekerja pada pekerjaan yang belum pernah ada pada hari ini. Penyebabnya, revolusi industri 4.0 dan society 5.0 berpotensi memberikan peningkatan tenaga kerja hingga 2,1 juta pekerjaan baru pada tahun 2025 (Ahmad, 2018). Hal tersebut menjadi peluang dan tantangan bagi madrasah dan para guru dalam pendidikan, terutama untuk menghasilkan lulusan yang mampu bersaing di era revolusi industri 4.0 dan society 5.0.

Sekolah/Madrasah harus mampu menghasilkan lulusan yang memiliki skill yang dibutuhkan pada era revolusi industri 4.0 dan society 5.0 (Forum, 2018). Terdapat lima skill utama yang harus dimiliki generasi muda bangsa Indonesia sebagai berikut.

\section{Complex Problem Solving}

Complex problem solving adalah kemampuan untuk memecahkan masalah yang asing dan belum diketahui solusinya di dalam dunia nyata.

\section{Social Skill}

Social skill adalah kemampuan untuk melakukan koordinasi, negosiasi, persuasi, mentoring, kepekaan dalam memberikan bantuan hingga emotional intelligence.

3. Process Skill

Process skill adalah kemampuan yang terdiri dari active listening, logical thinking, dan monitoring self and the others.

\section{System Skill}

System skill adalah kemampuan untuk dapat melakukan judgement dan keputusan dengan pertimbangan cost-benefit serta kemampuan untuk mengetahui bagaimana sebuah sistem dibuat dan dijalankan.

5. Cognitive Abilities

Cognitive abilities adalah skill yang terdiri dari antara lain: Cognitive Flexibility, Creativity, Logical Reasoning, Problem Sensitivity, Mathematical Reasoning, dan Visualization.

Madrasah Aliyah Al-Ishlah merupakan salah satu sekolah menengah swasta yang ada di Kecamatan Bungkal, Kabupaten Ponorogo, Jawa Timur. Madrasah ini memiliki semangat yang tinggi untuk senantiasa mengoptimalkan pelbagai potensi siswa-siswinya. Salah satu kegiatan yang disepakati bersama adalah dengan adanya pelatihan blended learning. Selama ini para guru di Madrasah Aliyah Al-Ishlah Bungkal Ponorogo masih mengajar secara konvensional.

Blended learning adalah suatu 
pembelajaran yang mengombinasikan antara pembelajaran dalam jaringan (daring) dan tatap muka atau luar jaringan (luring) (Graham, 2006; Singh, 2003; Valiathan, 2002). Banyak penelitian menunjukkan bahwa blended learning mampu efektif meningkatkan prestasi belajar peserta didik (Chen \& Jones, 2007; Means et al., 2013; Pereira et al., 2007).

Pada dasarnya banyak telah dikembangkan aplikasi penunjang pembelajaran blended learning, diantaranya aplikasi seperti Absorb, Moodle, Canvas, Schoology, Blackboard Learn, D2L Brightspace, Edmodo, Quizlet dan Google Classroom (Suhandiah et al., 2019).

Kegiatan pengabdian masyarakat ini bertujuan untuk menyadarkan para guru tentang lahirnya society 5.0 dan implikasinya pada dunia pendidikan. Selanjutnya, para guru diberikan pelatihan pelaksanaan pembelajaran blended learning, khususnya dalam pemanfaatan Google Classroom untuk pembelajaran secara online.

\section{METODE PENELITIAN}

Pendekatan yang digunakan pada kegiatan pengabdian kepada masyarakat ini adalah participatory action research (PAR). PAR merupakan salah satu pendekatan yang mengombinasikan antara penelitian dengan tindakan yang berkelanjutan (Kindon et al., 2007; Ottosson, 2003) dan dilakukan secara partisipatif bersama masyarakat. Berpijak pada problematika yang dihadapi oleh subjek dampingan, menjadikan PAR sebagai pilihan metode yang tepat sebagai upaya untuk memberikan alternatif solusi pemecahan masalah yang ada (Irawan, 2019).

Subjek dampingan pada kegiatan ini adalah Madrasah Aliyah Al-Ishlah Bungkal, Slahung, Ponorogo, Jawa Timur. Kegiatan yang dilaksanakan pada bulan Oktober 2019 ini merupakan salah satu solusi yang ditawarkan oleh pelaksana pengabdian dan disepakati oleh madrasah.

Secara teknis, kegiatan ini terdiri dari tiga tahapan sebagaimana tercantum pada gambar tahapan kegiatan pengabdian berikut.

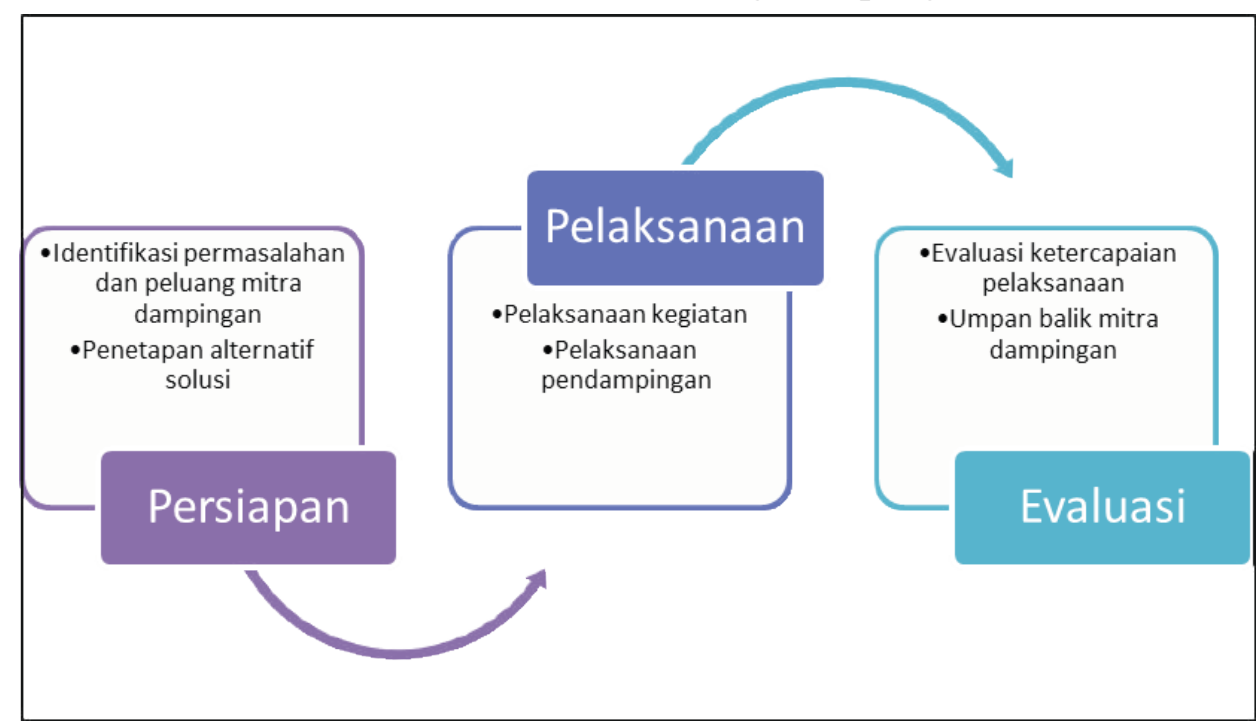

Gambar 1: Alur Pelaksanaan Pengabdian Masyarakat 
Tingkat keberhasilan pelaksanaan program dievaluasi menggunakan pre test dan post tes serta lembar evaluasi oleh subjek dampingan, yaitu pada guru Madrasah Aliyah Al-Ishlah Bungkal.

\section{HASIL DAN PEMBAHASAN}

Pelaksanaan kegiatan pengabdian kepada masyarakat ini dilaksanakan dalam tiga tahapan sebagai berikut.

\section{Persiapan}

Kegiatan yang ini dilaksanakan pada tanggal 26 September 2019 bertujuan untuk mengidentifikasi dan memilih fokus permasalahan. Identifikasi masalah dilakukan bersama dengan kepala madrasah dan wakil kepala madrasah.

Hasil pelaksanaan pada tahap pertama ini adalah masih belum familiar tentang revolusi industri 4.0 dan society 5.0 pada guru maupun siswa di Madrasah Aliyah Al-Ishlah
Bungkal. Selainitu, pembelajaran yang dilakukan selama ini masih bersifat konvensional, belum dilakukan atau dikombinasikan dengan pembelajaran online.

Data di atas juga diperkuat dengan hasil survei awal yang dilakukan terhadap para guru di Madrasah Aliyah Al-Ishlah Bungkal sebagaimana tercantum pada grafik gambar 2 ..

\section{Pelaksanaan}

Pelaksanaan kegiatan inti yang merupakankesepakatan antaraolehtim pelaksana pengabdian dengan subjek dampingan. Kegiatan inti dimulai dari brainstorming tentangrevolusiindustri 4.0 dan society 5.0. Sebagian peserta masih asing dengan istilah revolusi industri 4.0. Terlebih terhadap society 5.0 belum pernah mendengar atau bahkan mendalaminya. Oleh karena itu, dipaparkan tentang ciri utama masing-masing tahapan revolusi industri, mulai dari revolusi industri

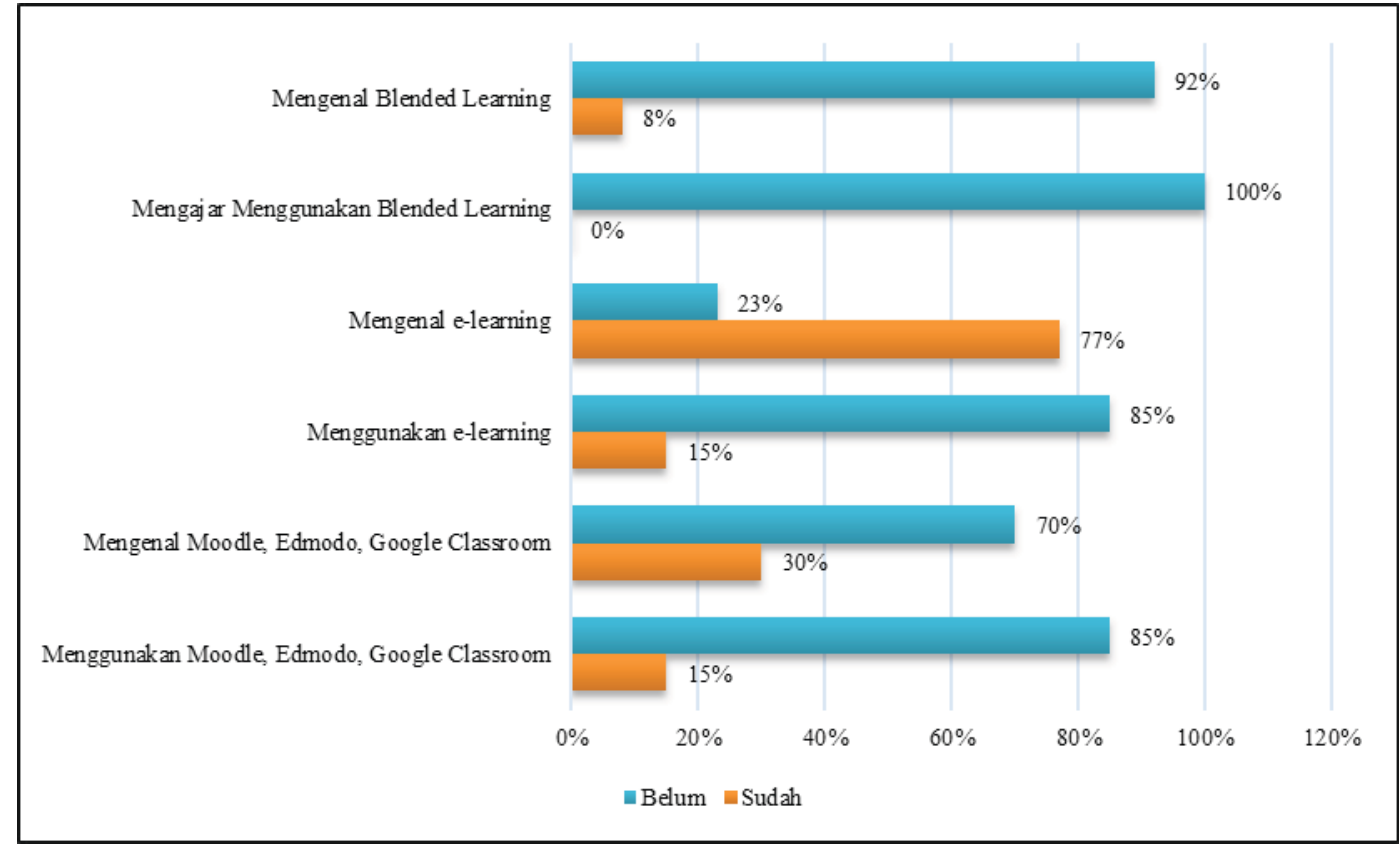

Gambar 2: Kondisi Awal Para Guru Madrasah Aliyah Al-Ishlah Bungkal 


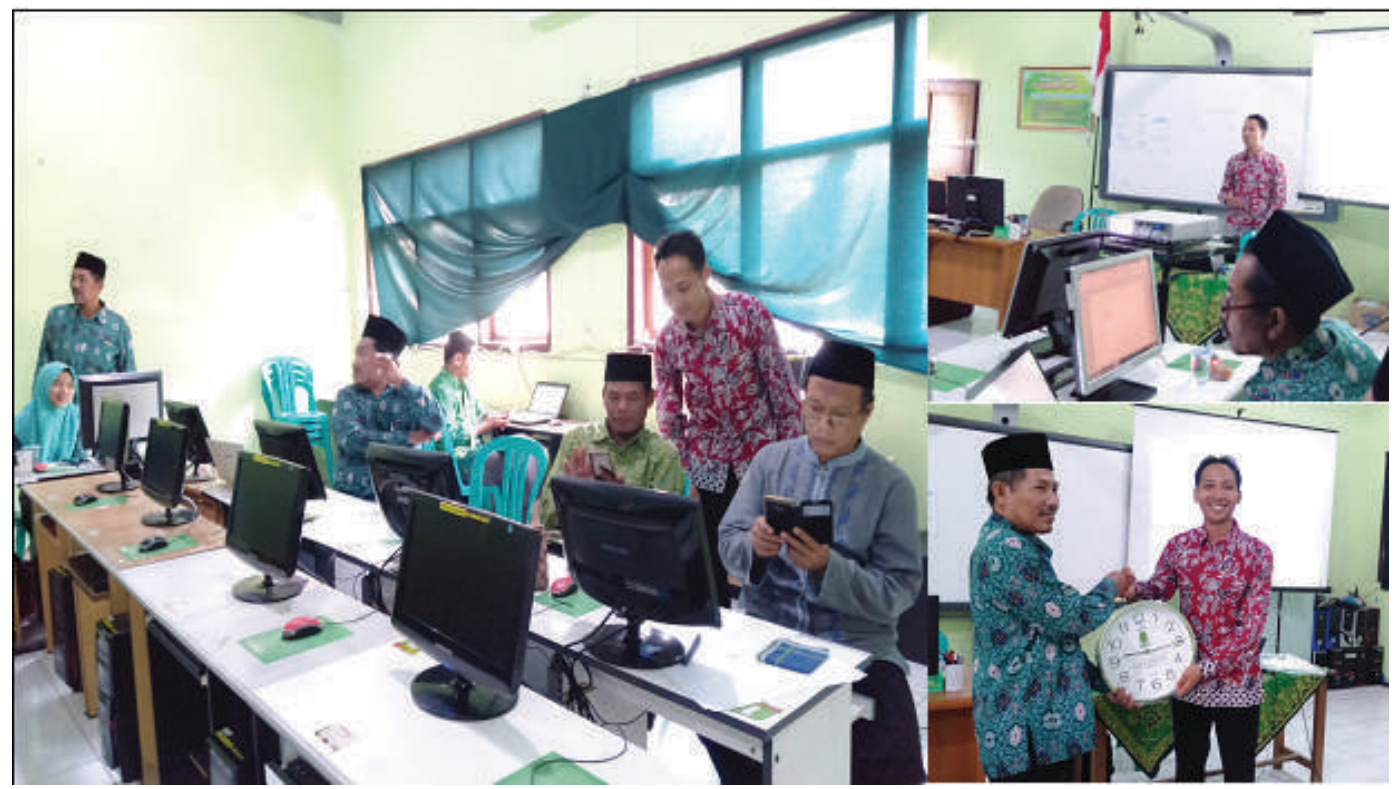

Gambar 3: Proses Pelaksanaan Pelatihan Blended Learning Menggunakan Google Classroom

1.0, kemudian revolusi industri 2.0, revolusi industri 3.0, dan revolusi industri 4.0. Revolusi industri 4.0 ditandai dengan keberadaan robot, sensor, mesin cetak tiga dimensi, dan artificial intelegensi/kecerdasan buatan yang dimanfaatkan untuk mendukung industri.

Selanjutnya, disampaikan tentang tahapan society, mulai dari society 1.0 hingga society 5.0. Society 1.0 ditandai dengan manusia hidup dengan berburu, kemudian society 2.0 ditandai dengan manusia yang sudah mengenal bercocok tanam. Selanjutnya, society 3.0 ditandai dengan manusia sudah mengenal industri dan society 4.0 yang ditandai dengan manusia sudah mengenal teknologi informasi dan komunikasi. Society 5.0 merupakan fase termutakhir dimana peradaban manusiadiwarnai dengan pemanfaatan artificial intelegensi/kecerdasan buatan, big data, robotika, dan sensor. Jika revolusi industri menekankan pada pentahapan perkembangan dunia industri, maka konsep society lebih menekankan pada peradaban manusia.

Selanjutnya, para guru diberikan pelatihan tentang blended learning. Pembelajaran yang mengombinasikan antara pembelajaran tatap muka (luring) dan dalam jaringan (daring/ online).Pembelajarandaringdilakukan dengan menggunakan aplikasi Google Classroom. Karenanya, para guru Madrasah Aliyah Al-Ishlah Bungkal dilatih untuk memanfaatkan Google Classroom.

Pelatihan dimulai dari pengenalan Google Classroom, kelebihan, kekurangan, dan berbagai menu yang dapat dimanfaatkan. Kemudian dilanjutkan tentang prosedur membuat akun pengajar pada Google Classroom. Kemudian, satu per satu diperkenalkan prosedur membuat pengumuman, mengunggah materi, melampirkan tautan, memberikan 


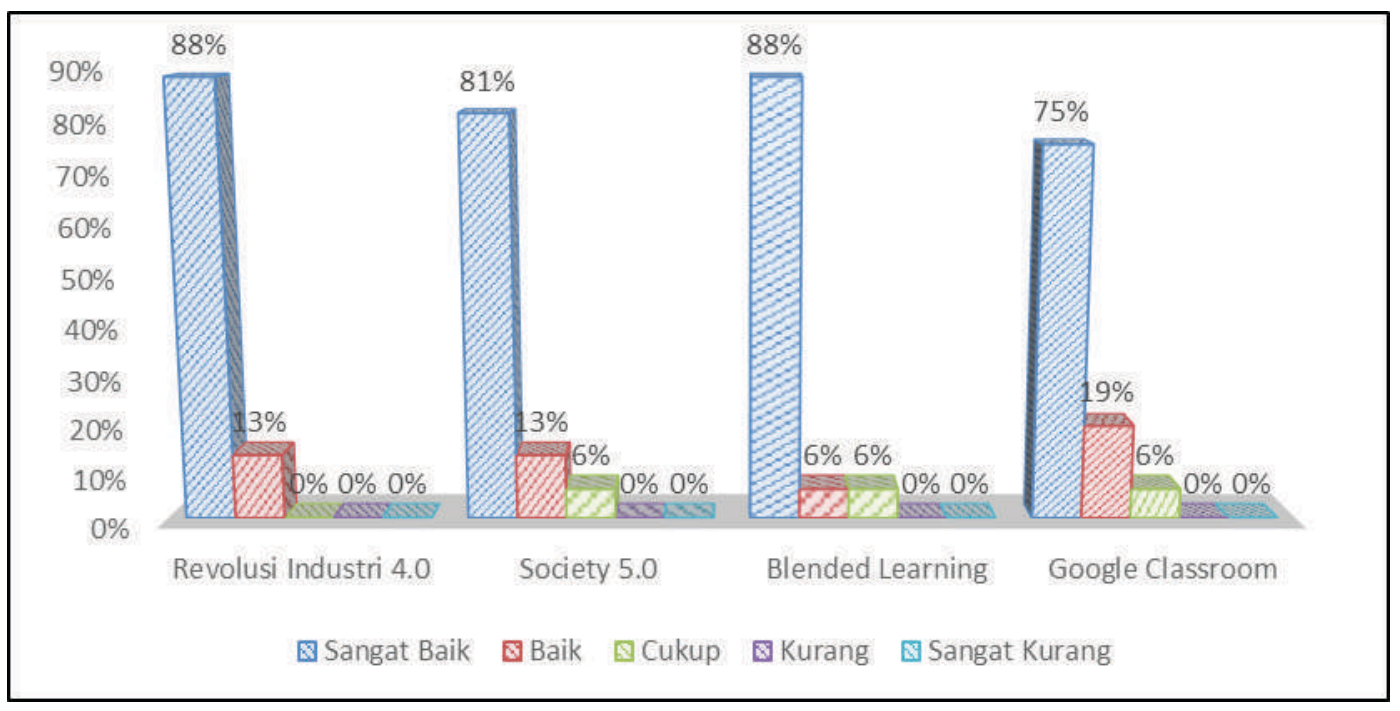

Gambar 4: Tingkat Pemahaman Peserta Terhadap Materi Pelatihan

tugas kepada siswa, mengoreksi tugas siswa, membuat soal pilihan ganda, dan mengunduh rekap nilai pada Google Classroom. Selanjutnya, para guru yang menjadi subjek dampingan, langsung mempraktikkan berbagai tahapan tersebut. Tim pelaksana pengabdian mendampingi dan memberikan solusi terhadap masalah atau kendala yang dihadapi para guru dalam mempraktikkan pemanfaatan Google Classroom.
Setelah pelatihan, diberikan kuis untuk mengetahui penguasaan peserta terhadap materi. Kuis yang diberikan mencakup seluruh materi yang diberikan sebelumnya. Pelaksanaannya, dilakukan melalui laman https://kahoot.com. Hasil kuis yang menjadi indikator penguasaan materi peserta tersajikan pada gambar 4. Peserta yang mendapatkan skor tertinggi selanjutnya diberikan hadiah

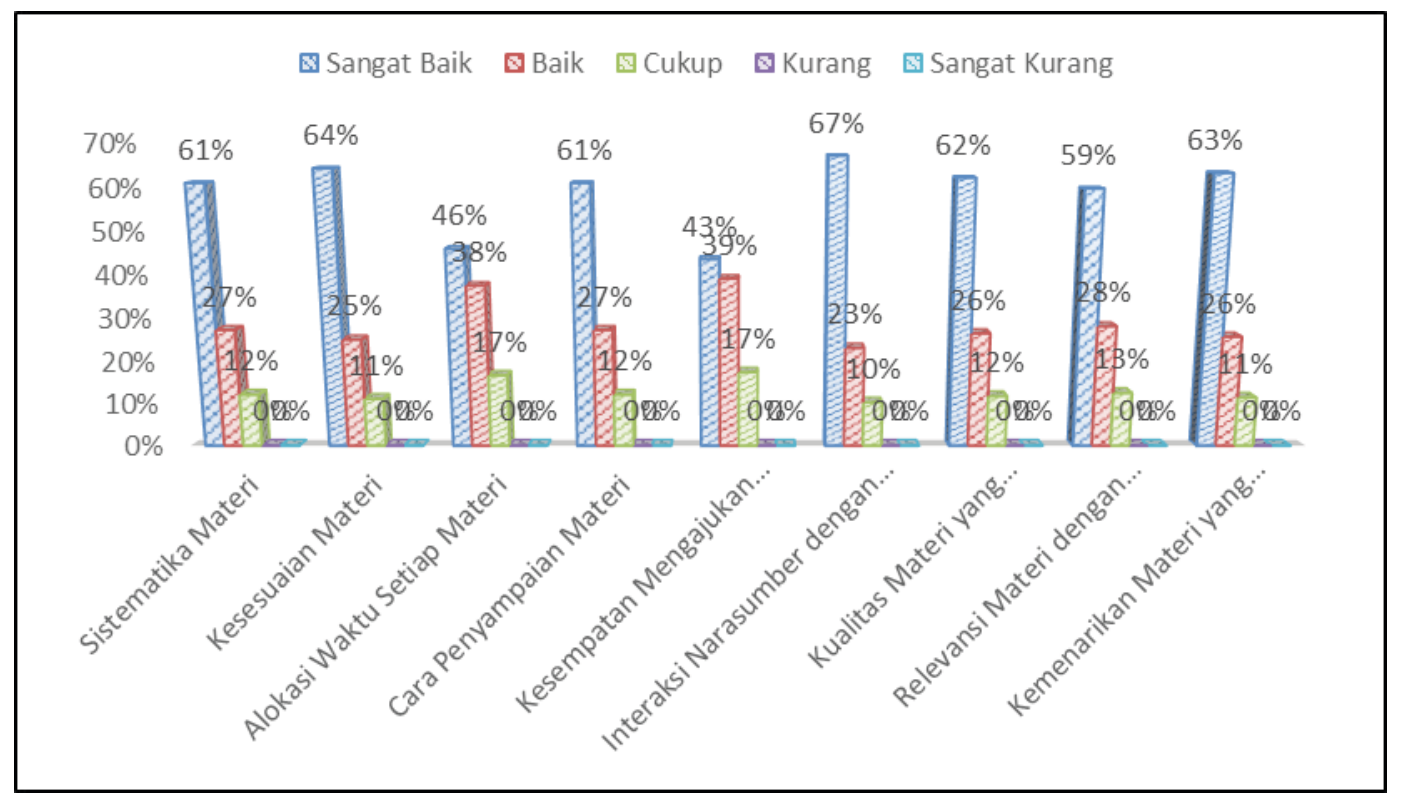

Gambar 5: Hasil Evaluasi Peserta Terhadap Kegiatan Pelatihan 
sebagaimana terdokumentasikan pada gambar 3.

\section{Evaluasi}

Pada akhir kegiatan dilakukan evaluasi dengan memberikan angket secara online kepada para peserta tentang sembilan kriteria, yaitu sistematika materi, kesesuaian materi, alokasi waktu setiap materi, cara penyampaian materi, kesempatan mengajukan pertanyaan, interaksi narasumber dengan peserta seminar, kualitas materi yang disampaikan, relevansi materi dengan kebutuhan, kemenarikanmateriyangdisampaikan. Hasilnya sebagaimana tersaji pada gambar 5.

Pada gambar 5, terlihat bahwa berdasarkan evaluasi para peserta, pada aspek sistematika materi, kesesuaian materi, cara penyampaian materi, interaksi narasumber dengan peserta seminar, kualitas materi yang disampaikan, relevansi materi dengan kebutuhan, dan kemenarikan materi yang disampaikan relatif sangat baik, dengan persentase penilaian sangat baik melampaui $60 \%$ responden, dan hanya berkisar $12 \%$ responden yang menyatakan cukup. Sedangkan pada aspek alokasi waktu setiap materi, kesempatan mengajukan pertanyaan, relatif baik, dengan persentase penilaian sangat baik dan baik berkisar pada $40 \%$ dan hanya berkisar $17 \%$ responden yang menyatakan cukup. Hal ini merupakan salah satu indikasi positif bahwa kegiatan pengabdian kepada masyarakat ini diterima dengan baik dan bermanfaat bagi subjek dampingan.

\section{SIMPULAN}

Berdasarkan hasil pelaksanaan dan pembahasan di atas, dapat disimpulkan sebagai berikut.

1. Hadirnya revolusi industri 4.0 dan society 5.0 belum banyak diketahui oleh masyarakat termasuk di dunia pendidikan menengah. Oleh karena itu, sangat penting untuk dilakukan edukasi tentang hal tersebut, sekaligus memberikan solusi untuk segera mempersiapkan diri agar mampu memanfaatkan peluang yang ada.

2. Salah satu solusi yang ditawarkan dengan memberikan pengenalan dini terhadap revolusi industri 4.0 dan society 5.0 sekaligus tentang blended learning dengan memanfaatkan GoogleClassroom, mampu memberikan dampak pengetahuan dan keterampilan yang signifikan pada subjek dampingan, yaitu pada guru di Madrasah Aliyah Al-Ishlah, Bungkal, Ponorogo.

3. Keberhasilan kegiatan pengabdian kepada masyarakat ini tercermin pada hasil umpan balik dari para peserta. Sebagian besar peserta memberikan penilaian yang sangat baik, baik terhadap aspek yaitu sistematika materi, kesesuaian materi, alokasi waktu setiap materi, cara penyampaian materi, kesempatan mengajukan pertanyaan, interaksi narasumber dengan peserta seminar, kualitas materi yang disampaikan, relevansi materi dengan kebutuhan, maupun kemenarikan materi yang disampaikan.

\section{DAFTAR PUSTAKA}

Ahmad, I. (2018). Proses
pembelajaran digital dalam era
revolusi industri 4.0.

Chen, C. C., \& Jones, K. T. 
(2007). Blended Learning vs Traditional Classroom Settings: Assessing Effectiveness and Student Perceptions in an MBA Accounting Course. Journal of Educators Online, 4(1), n1.

Forum, W. E. (2018). The future of jobs report 2018.

Graham, C. R. (2006). Blended Learning Systems. The Handbook of Blended Learning, 3-21.

Harayama, Y. (2017). Society 5.0: Aiming for a New Humancentered Society. Japan's Science and Technology Policies for Addressing Global Social Challenges. Hitachi Review, 66(6), 556-557.

Irawan, E. (2019). Digitalisasi Madrasah di Era Revolusi Industri 4.0: Refleksi Kegiatan Pengabdian Kepada Masyarakat di Kabupaten Ponorogo. E-Dimas: Jurnal Pengabdian Kepada Masyarakat, 10(2), 160-168.

Kindon, S., Pain, R., \& Kesby, M. (2007). Participatory action research approaches and methods: Connecting people, participation and place. Routledge.

Leonhard, G. (2016). Technology vs. Humanity: The coming clash between man and machine. FutureScapes.

Means, B., Toyama, Y., Murphy, R., \& Baki, M. (2013). The Effectiveness of Online and Blended Learning: A Metaanalysis of the Empirical Literature. Teachers College Record, 115(3), 1-47.

Ottosson, S. (2003). Participation action research-: A key to improved knowledge of management. Technovation, 23(2), 87-94.

Pereira, J. A., Pleguezuelos, E., Merí, A., Molina-Ros, A., Molina-
Tomás, M. C., \& Masdeu, C. (2007). Effectiveness of Using Blended Learning Strategies for Teaching and Learning Human Anatomy. Medical Education, 41(2), 189-195.

Salgues, B. (2018). Society 5.0: Industry of the Future, Technologies, Methods and Tools. John Wiley \& Sons.

Schwab, K. (2017). The Fourth Industrial Revolution. Crown Business.

Shiroishi, Y., Uchiyama, K., \& Suzuki, N. (2018). Society 5.0: For human security and well-being. Computer, 51(7), 91-95.

Singh, H. (2003). Building Effective Blended Learning Programs. Educational Technology-Saddle Brook Then Englewood Cliffs NJ-, 43(6), 51-54.

Soemantri, S. (2019). Pelatihan Membuat Media Pembelajaran Digital. Aksiologiya: Jurnal Pengabdian Kepada Masyarakat, 3(1), 64-69.

Suhandiah, S., Sudarmaningtyas, P., \& Ayuningtyas, A. (2019). Pelatihan E-Learning Bagi Guru Untuk Optimalisasi Pembelajaran Generasi Z. Aksiologiya: Jurnal Pengabdian Kepada Masyarakat, 4(1).

Valiathan, P. (2002). Blended Learning Models. Learning Circuits, 3(8), 50-59. 